\title{
EVALUASI DAMPAK PELAKSANAAN PROGRAM PEMBINAAN DAN PENGEMBANGAN INDUSTRI KECIL DAN MENENGAH DI KABUPATEN PONOROGO
}

\section{IMPACT EVALUATION OF DEVELOPMENT PROGRAM OF SMALL AND MEDIUM INDUSTRY IN PONOROGO REGENCY}

\author{
Dina Trisiana Iskandar, Sumartono, Tjahjanulin Domai \\ Magister Ilmu Administrasi Publik, Fakultas Ilmu Administrasi \\ Universitas Brawijaya, Jl. MT Haryono No. 163 Malang \\ e-mail:d_trisiana03@yahoo.com
}

Naskah diterima: 29 November 2016, revisi pertama: 30 November 2016, revisi kedua: 17 Maret 2017, revisi ketiga: 6 April 2017 disetujui 17 April 2017.

\begin{abstract}
Astract
This research is part of thesis that aims to evaluate the impact of the implementation program of development of small and medium industries in Ponorogo Regency, such as the impact of increasing the skills and improving the welfare of SMEs. The method used is descriptive qualitative evaluation. The evaluation results show that the program's goals include increased skills not optimum. It is evident from the interviews that output of this program to increase the knowledge of SMES. But, because this knowledge is only basic level, where after joining the training, SMEs will find new information and knowledge, so the technical and management skills of SME entrepreneurs not increase properly. However, it should be noted that through the impact evaluation there is improvement of SME's skills in the product quality. On the other hand, through impact evaluation the welfare improvement is not maximal yet in order to upgrade sales turnover. From the result of this evaluation, the lack of monitoring and evaluation causing the program has not been successful in achieving target. The monitoring and evaluation process are needed to analyze the problems and make some alternative solutions, so the regional development planning can be effective and efficient.
\end{abstract}

Keywords: Impact evaluation, SME development, welfare

\begin{abstract}
Abstrak
Penelitian ini merupakan bagian dari tesis yang bertujuan untuk mengevaluasi dampak pelaksanaan program pembinaan dan pengembangan IKM di Kabupaten Ponorogo, berupa dampak peningkatan keterampilan danpeningkatan kesejahteraan IKM. Metode penelitian yang digunakan adalah evaluasi kualitatif deskriptif. Evaluasi hasil menunjukkan bahwa tujuan program berupa peningkatan keterampilan belum sepenuhnya optimal.
\end{abstract}


Hal ini terlihat dari hasil wawancara bahwa output program ini berwujud terhadap peningkatan pengetahuan pengrajin IKM, yang merupakan tahap permulaan, dimana setelah mengikuti pelatihan menjadikan pengrajin IKM mendapatkan informasi dan pengetahuan baru, dan belum menunjukkan peningkatan keterampilan teknis maupun manajerial. Selanjutnya melalui evaluasi dampak terlihat adanya peningkatan keterampilan IKM berupa perbaikan kualitas dan mutu produk yang dihasilkan. Sedangkan melalui evaluasi dampak peningkatan kesejahteraan masih belum maksimal dalam upaya meningkatkan omzet penjualan. Berdasarkan hasil evaluasi tersebut, minimnya monitoring dan evaluasi menyebabkanprogram belum berhasil optimal dalam mencapai target. Perlunya proses monitoring dan evaluasi tersebut agar dapat dianalisis permasalahan dan menghasilkan alternatif solusi, sehingga perencanaan pembangunan daerah dapat berjalan secara efektif dan efisien.

Kata Kunci: evaluasi dampak, pengembangan IKM, kesejahteraan

\section{A. PENDAHULUAN}

Pada era globalisasi seperti saat ini berdampak luas terhadap perekonomian nasional, baik positif maupun negatif. Globalisasi memiliki pengertian “borderless” dimana peran batas-batas negara menjadi minimal dalam rangka mendorong kemudahan bagi aktivitas masyarakat. Bahkan di penghujung tahun 2015 yang lalu, Indonesia telah menghadapi Masyarakat Ekonomi ASEAN (ASEAN Economic Community) yang menjadikan fenomena kompetisi industri yang semakin keras, tantangan bagi industri nasional dengan kemudahan masuknya produk-produk asing, sehingga diperlukan suatu upaya nyata dalam mendukung pengembangan industri nasional melalui penciptaan nilai tambah dalam negeri dengan memanfaatkan potensi sumber daya alam secara optimal dan bijak olehindustri nasional dan peningkatan peran serta Pemerintah secara langsung. Kecenderungan ini mendorong tumbuhnya kolaborasi antara perusahaan indusri sehingga membentuk jaringan rantai pasok global (global value chain) yang memungkinkan terciptanya nilai tambah yang tinggi namun dengan biaya yang ekonomis. Disisi lain, dampak negatif yang terjadi adalah serbuan produk-produk impor, sehingga diperlukan perlindungan industri dalam negeri seperti anti-dumping,anti subsidy, safeguard dan instrumen lainnya (Renstra Kemenperin 2015-2019:85). Sejalan dengan tujuan nasional khususnya dalam sektor ekonomi, maka diharapkan industri memiliki keunggulan bersaing (competitive advantage), dalam menghadapi era globalisasi yang ditandai dengan persaingan, kerjasama, perubahan, penemuan, teknologi dan informasi baru antarnegara (Nugroho, 2003:27).

Mengacu pada fokus prioritas pembangunan industri, salah satu langkah dalam mencapai pembangunan ekonomi lokal adalah keterlibatan masyarakat dalam memanfaatkan sumberdaya lokal melalui pemberdayaan Industri Kecil dan Menengah (IKM), yang diyakini mampu menjadi motor penggerak dalam perekonomian rakyat. Melalui pembangunan dan pemberdayaan IKM diharapkan dapat mewujudkan IKM yang berdaya saing tinggi, berperan dalam penguatan struktur industri nasional, berperan serta dalam pengentasan kemiskinan, perluasan kesempatan kerja, serta menghasilkan produk barang dan/atau jasa industri untuk diekspor. Berdasarkan data dari Kementerian Perindustrian, IKM memiliki peran yang strategis dalam perekonomian nasional, yang dapat dilihat melalui kontribusi PDB IKM terhadap PDB Industri Nasional sebesar 34,82\% tahun 2015 (LAKIP Kementerian Perindustrian 2015). Selain berkontribusi terhadap perekonomian, IKM juga memiliki keunggulan resisten terhadap terpaan krisis global karena ciri khasnya mengolah barang setengah jadi maupun jadi dari sumberdaya lokal. 
Kabupaten Ponorogo yang terletak di sebelah barat daya dari ibukota Provinsi Jawa Timur, memiliki nilai komparatif berupa ketersediaan lahan pertanian yang subur yang menjadikan Ponorogo sebagai daerah berbasis sektor primer, dengan kontibusi sektor pertanian, kehutanan dan perikanan terhadap Pendapatan Regional Domestik Bruto (PDRB) Kabupaten Ponorogo pada tahun 2015 mencapai 31,80\% dengan nilai Rp.4.274.965,4 juta. Sedangkan kontribusi PDRB dari sektor industri pengolahan hanya sebesar 6,75\% dengan nilai Rp.906.868,86 juta (BPS Kabupaten Ponorogo, 2016). Ironisnya, persentase penduduk miskin Ponorogo mengalami peningkatan dari 11,53\% pada tahun 2014menjadi $12,19 \%$ pada tahun 2015. Sehingga, tidak cukup hanya mengandalkan nilai tawar komparatif, perlu adanya nilai tawar kompetitif salah satunya melalui pemberdayaan sektor IKM. Hal ini sejalan dengan pendapat yang disampaikan Spicer dalam Rakicevic (2015:3) menjelaskan pentingnya keberadaan IKM yang dikenal sebagai motor penggerak pertumbuhan ekonomi nasional, regional dan pengembangan sumberdaya lokal, serta sebagai alat untuk mencegah perpindahan penduduk dari area geografi-ekonomi yang pasif.

Sama halnya daerah lain, corak struktur industri di Kabupaten Ponorogo sebagian besar merupakan IKM, dengan jumlah industri pada tahun 2014 sebanyak 3 industri besar, 22 industri sedang dan IKM sebanyak 19.706 unit. Selengkapnya dapat dilihat pada Tabel 1.

Tabel 1.

Perkembangan Jumlah Industri di Kabupaten Ponorogo

\begin{tabular}{|c|c|c|c|c|c|c|}
\hline \multirow{2}{*}{ No } & \multirow{2}{*}{$\begin{array}{c}\text { Jenis } \\
\text { Industri }\end{array}$} & \multicolumn{5}{|c|}{ Jumlah (unit) } \\
\hline & & 2011 & 2012 & 2013 & 2014 & 2015 \\
\hline 1 & Besar & 5 & 4 & 6 & 3 & 4 \\
\hline 2 & Sedang & 37 & 43 & 18 & 22 & 23 \\
\hline 3 & Kecil & 21.857 & 21.872 & 19.685 & 19.706 & 19.708 \\
\hline & Jumlah & 21.834 & 21.899 & 21.919 & 19.731 & 19.735 \\
\hline
\end{tabular}

Sumber: BPS Ponorogo (2016:191)

Rendahnya pertumbuhan industri khususnya IKM menjadi perhatian khusus terhadap kinerja Pemerintah Kabupaten Ponorogo melalui Dinas Indakop dan UKM sebagai leading sector dalam pembangunan ekonomi dari sektor industri melalui program pembinaan dan pengembangan IKM yang telah dilaksanakan pada periode 2011-2015. Berdasarkan permasalahan tersebut dimana hingga akhir tahun perencanaan belum mampu mencapai target yang diharapkan. Tulisan ini akan menjawab bagaimana evaluasi dampak dari pelaksanaan program pembinaan dan pengembangan IKM di Kabupaten Ponorogo berupa dampak peningkatan keterampilan dan dampak kesejahteraan pengrajin IKM?Adapun pemilihan evaluasi pada periode lalu 2010-2015, dikarenakan adanya pergantian Kepala Daerah yang baru (bukan petahana), sehingga hasil evaluasi ini diharapkan dapat memberikan masukan kepada Bupati terpilih mengenai dampak yang diterima pengrajin IKM sebagai sasaran dalam program ini, sehingga terjadi adanya kesinambungan program.

\section{B. METODE PENELITIAN}

Menurut Guba dan Lincoln dalam Abdul Wahab (2011:35) bahwa metode penelitian kualitatif paling tepat untuk melaksanakan evaluasi program-program sosial atau disebut metode etnografis (ethnographic method), lebih unggul ketimbang pendekatan-pendekatan kuantitatif yang lebih terstruktur, karena mampu memberikan nuansa dan spektrum sosial yang relatif lebih leluasa dan 
fleksibel. Fokus penelitian ini yaitu evaluasi dampak pelaksanaan program pembinaan dan pengembangan IKM di Kabupaten Ponorogo, berupa: (1) evaluasi dampak peningkatan keterampilan IKM; dan (2) evaluasi dampak peningkatan kesejahteraan IKM.

Informan yang digunakan sebagai sumber data dipilih secara purposif (purposive sampling), yakni 11 (sebelas) orang pejabat dan staf di lingkup Dinas Industri Perdagangan Koperasi dan UKM, diantaranya: Kepala Dinas, Kepala Bidang Industri, Kasi Sungram, Kasi IHPK, Kasi IKBB, Kasi ILMEA beserta staf, dan Kasi Sungram BAPPEDA. Serta 12 (dua belas) pengrajin IKM sebagai sasaran penerima program, sebanyak 6 (enam) pengrajin IKM yang telah mendapatkan pelatihan dalam program pembinaan dan pengembangan IKM dan 6 (enam) pengrajin IKM belum mendapatkan pelatihan dalam programtersebut.

Analisis data yang digunakan, yaitu model analisis evaluasi kualitatif yang dikembangkan oleh Patton (2006:251-255) yang terdiri dari 3 (tiga) komponen, yakni: (1) memfokuskan analisis; (2) mengorganisasikan data kualitatif untuk analisis; dan (3) deskripsi kualitatif yang mencakup deskripsi murni tentang program dan pengalaman orang dalam program.

\section{KERANGKA TEORI}

\section{Perencanaan Pembangunan Daerah}

Riyadi (2004:7) menjelaskan bahwa konsep perencanaan pembangunan daerah adalah suatu proses perencanaan pembangunan yang dimaksudkan untuk melakukan perubahan kearah lebih baik bagi komunitas masyarakat, pemerintah dan lingkungannya, dalam suatu daerah dengan pemanfaatan sumber daya secara menyeluruh, lengkap tapi tetap berpegang pada azas prioritas. Perencanaan pembangunan daerah dalam konteks pembangunan nasional memiliki peran dan fungsi yang sangat penting bagi pencapaian tujuan-tujuan pembangunan nasional. Dengan diberlakukannya otonomi daerah yang lebih luas, nyata dan bertanggung jawab, setiap daerah dituntut untuk mampu mengelola daerahnya secara mandiri. Sehingga Pemerintah Daerah harus memiliki daya kreativitas yang tinggi, terutama yang berhubungan dengan upaya-upaya menggali potensi-potensi daerahnya secara optimal dan mengembangkan secara inovatif potensi-potensi yang sudah ada.

Lebih lanjut Riyadi (2004:44) menjelaskan bahwa perencanaan pembangunan daerah (PPD) dalam konteks pembangunan nasional memiliki peran penting bagi pencapaian tujuan-tujuan pembangunan nasional. Strategi pembangunan nasional akan lebih mempertimbangkan potensi dan dinamika perkembangan daerah dan wilayah. Perencanaan nasional diarahkan pada pengembangan pusat-pusat pertumbuhan (growth pole) sesuai dengan keunggulan komparatif di masing-masing wilayah. Pemerintah pusat hanya akan melakukan program-program pembangunan yang memiliki karakter kepentingan nasional (national interest) atau bersifat strategis (national strategis).Dengan demikian, hubungan hierarki antar jenis pemerintahan pusat digantikan dengan hubungan koordinatif antar daerah, antara daerah dan pusat tetap diperlukan dalam konteks persatuan dan kesatuan bangsa.

\section{Implementasi Perencanaan}

Suatu perencanaan yang baik, belum tentu dapat diimplementasikan dengan sempurna. Pressman sebagaimana dikutip dalam Conyers dan Hills (1990:155) memaparkan pengertian implementasi mungkin dapat dipandang sebagai sebuah proses interaksi antara suatu perangkat tujuan dan tindakan yang mampu untuk meraihnya. Pelaksanaan atau implementasi program dengan demikian telah menjadi suatu jaringan yang tak nampak. Implementasi adalah kemampuan untuk 
membentuk hubungan-hubungan lebih lanjut dalam rangkaian sebab akibat yang menghubungkan tindakan dengan tujuan.

Selanjutnya Conyers (1990:156-158) menjelaskan dalam proses implementasi rencana, dapat dipengaruhi oleh berbagai faktor, seperti yang diungkapkan bahwa faktor-faktor yang mempengaruhi implementasi rencana antara lain:

1. Sifat dari proses perencanaan

Permasalahan implementasi rencana umumnya disebabkan karena perencanaan dan implementasi cenderung dianggap seperti dua kegiatan yang terpisah dan tidak berhubungan. Permasalahan ini dapat di atasi dengan mengadopsi pendekatan baru, dimana persiapan dan implementasi rencana dipandang sebagai proses siklus yang terus-menerus;

2. Organisasi perencanaan dan implementasi

Konsep perencanaan sebagai proses siklus terus-menerus menyiratkan bahwa perencanaan melibatkan beragam individu dan organisasi. Hubungan timbal balik antar berbagai pihak pada persiapan dan implementasi rencana akan mempengaruhi isi rencana dan proses pelaksanaannya. Sehingga, banyak permasalahan implementasi yang disebabkan oleh faktor organisasi, termasuk lemahnya koordinasi antara perencana professional yang terlibat langsung maupun tidak langsung dalam proses perencanaan;

3. Isi rencana

Banyak permasalahan implementasi kegiatan yang terjadi berulang kali disebabkan pada tahap perencanaan atau desain yang antara lain pada waktu mengakomodasi unsur ketidakpastian dan mengusahakan agar lebih fleksibel namun malah menyebabkan desain proyek tidak bisa menjadi pedoman bagi pelaksana. Oleh karena itu, rencana yang baik hendaknya bersifat realistis dan perencanaan yang realistis tidak mungkin tidak dapat dicapai;

4. Manajemen proses implementasi

Implementasi meliputi pergerakan, pengorganisasian dan pengelolaan sumberdaya yang dibutuhkan untuk melakukan tindakan yang termasuk dalam perencanaan. Sumberdaya ini termasuk keuangan, tenaga kerja dan peralatan. Banyak perencanaan, terutama yang realistis, banyak yang tidak diterpkan seperti yang telah direncanakan karena sumberdaya yang tersedia tidak dalam jumlah yang tepat, di tempat yang tepat, dan pada waktu yang tepat. Dalam kasus ini mungkin disebabkan kurangnya koordinasi antara penyusunan rencana dan prosedur yang digunkan untuk mengalokasikan sumberdaya. Jadi salah satu hambatan untuk implementasi rencana di banyak negara adalah kurangnya koordinasi antara penyusunan rencana dan proses penganggaran tahunan”.

Kesuksesan perumusan strategi tidak dapat memberikan jaminan bahwa implementasinya akan berjalan sukses pula. Korelasi antara perumusan strategi dan implementasinya diungkapkan oleh Bonoma dalam Salusu (2015:242-243) sebagaimana dalam diagram berikut: 


\begin{tabular}{|c|c|c|}
\hline \multirow{2}{*}{$\begin{array}{c}\text { Implementasi } \\
\text { Strategi }\end{array}$} & \multicolumn{2}{|c|}{ Formulasi Strategi } \\
\hline & Tepat & Tidak Tepat \\
\hline Ekselen & $\begin{array}{l}\text { Sukses } \\
\text { Sasaran pertumbuhan } \\
\text { dinikmati oleh semua pihak } \\
\text { dan keuntungan yang } \\
\text { diharapkan tercapai }\end{array}$ & $\begin{array}{l}\text { Selamat atau Runtuh } \\
\text { Implementasi yang baik, } \\
\text { membantu menyelamatkan } \\
\text { strategi yang kurang baik } \\
\text { rumusannya, atau mencegah } \\
\text { kegagalan }\end{array}$ \\
\hline Buruk & $\begin{array}{l}\text { Kesulitan } \\
\text { Implementasi yang buruk, } \\
\text { merintangi strategi yang baik. } \\
\text { Manajemen bisa keliru } \\
\text { menafsirkan bahwa } \\
\text { strateginya kurang cepat }\end{array}$ & $\begin{array}{l}\text { Kegagalan } \\
\text { Sebab kegagalan sulit dikenali. } \\
\text { Startegi yang buruk ditandai } \\
\text { dengan ketidakmampuan } \\
\text { melaksanakannya }\end{array}$ \\
\hline
\end{tabular}

Gambar 1.

Korelasi antara Rumusan Strategi dan Implementasi Strategi

Sumber: Bonoma dalam (Salusu, 2015)

\section{Evaluasi Program}

Definisi evaluasi menurut Dunn (2003:608) secara umum dapat disamakan dengan penaksiran (appraisal),pemberian angka (rating) dan penilaian (assessment), kata-kata yang menyatakan usaha untuk menganalisis hasil kebijakan dalam arti satuan nilainya. Sedangkan dalam artian lebih spesifik, evaluasi berkenaan dengan produksi informasi mengenai nilai atau manfaat hasil kebijakan.

Sementara itu, Weiss dalam Abdul Wahab (2011:86) menjelaskan program dan proyek pembangunan sosial itu sendiri sesungguhnya merupakan ciptaan atau produk politis dan hasil akhir dari proses negoisasi serta kompromi yang melibatkan sejumlah aktor: para politisi, pebisnis, administrator dan warga negara yang akan dalam literatur konvensional disebut sebagai kelompok sasaran (target group) atau pemetik manfaat (beneficiaries) dalam memperjuangkan sumber-sumber langka (scares resources). Sehingga tujuan penelitian evaluasi tidak lain adalah untuk menaksir secara kritis dan kemudian telah menetapkan apakah program atau proyek pembangunan tertentu telah mencapai tujuan atau hasil akhir yang diharapkan atau tidak.

Lebih khusus mengenai evaluasi dampak sebagaimana dijelaskan oleh Wirawan (2011:21) bahwa evaluasi dampak (outcome) merupakan evaluasi sumatif yaitu mengukur dan menilai keluaran serta akibat atau pengaruh dari program. Data yang dijaring antara lain mengenai: (a) hasil atau keluaran program apakah sesuai yang direncanakan; (b) jumlah dan jenis orang yang dilayani apakah sesuai dengan yang direncanakan; (c) pengaruh atau akibat dari program terhadap orang yang mendapatkan layanan dari sebelum dan sesudah mendapatkan layanan program; dan (d) evaluasi keluaran juga mengidentifikasi apa yang harus dilakukan agar pengaruh program dapat berlangsung terus-menerus.

Siklus manajemen perencanaan pemerintah mencakup 4 (empat) hal, yaitu: (1) perencanaan (planning): (2) penganggaran (budgeting); (3) pelaksanaan (implementing); dan (4) pemantauan dan evaluasi (monitoring and evaluation). Dengan melihat hal tersebut, maka hasil monitoring dan evaluasi akan menjadi dasar penyusunan rencana pembangunan siklus berikutnya. Berdasarkan Peraturan Menteri Dalam Negeri Nomor 54 Tahun 2010, tujuan adanya pengendalian (monitoring) dan evaluasi terhadap perencanaan pembangunan daerah untuk mewujudkan:

a. Konsistensi antara kebijakan dengan pelaksanaan dan hasil rencana pembangunan daerah;

b. Konsistensi antara RPJPD dengan RPJPN dan RTRW nasional;

c. Konsistensi antara RPJMD dengan RPJPD dan RTRW daerah; 
d. Konsistensi antara RKPD dengan RPJMD; dan

e. Kesesuaian antara capaian pembangunan daerah dengan indikator-indikator kinerja yang telah ditetapkan.

\section{Industri Kecil dan Menengah}

Pengertian industri menurut Undang Undang Nomor 3 Tahun 2014 adalah seluruh bentuk kegiatan ekonomi yang mengolah bahan baku dan/atau memanfaatkan sumber daya industri sehingga menghasilkan barang yang mempunyai nilai tambah atau manfaat lebih tinggi, termasuk jasa industri. Klasifikasi industri dibedakan menurut jumlah tenaga kerja yang dipekerjakan, yaitu: (1) industri besar, yaitu industri dengan jumlah tenaga kerja minimal 100 orang; (2) industri sedang, yaitu industri yang menyerap tenaga kerja 20-99 orang; (3) industri kecil, yaitu industri dengan tenaga kerja 5-19 orang; dan (4) industri rumah tangga, yaitu industri dengan jumlah tenaga kerja 1-4 orang (Kuncoro, 2007:177).

Memperjelas klasifikasi mengenai IKM sebagaimana tertulis dalam Peraturan Menteri Perindustrian RI Nomor 64 Tahun 2016 tentang Besaran Jumlah Tenaga Kerja dan Nilai Investasi Untuk Klasifikasi Usaha Industri, yakni:

Industri kecil dan menengah merupakan industri yang mempekerjakan paling banyak 19 (sembilan belas) orang tenaga kerja dan memiliki nilai investasi kurang dari Rp 1.000.000.000,00 atau mempekerjakan paling sedikit 20 (dua puluh) orang tenaga kerja dan memiliki nilai investasi paling banyak Rp.15.000.000.000,00 (lima belas milyar rupiah). Atau lebih jelas dapat terlihat pada Tabel 2. sebagai berikut:

Tabel 2.

Besaran Jumlah Tenaga Kerja dan Nilai Investasi Untuk Klasifikasi Usaha Industri

\begin{tabular}{|l|l|l|l|}
\hline \multicolumn{1}{|c|}{$\begin{array}{c}\text { Nilai } \\
\text { Tenvestasi } \\
\text { Kerja }\end{array}$} & $<\mathbf{R p 1 . 0 0 0 . 0 0 0 . 0 0 0}$ & $\begin{array}{l}\mathbf{R p l . 0 0 0 . 0 0 0 . 0 0 0 -} \\
\mathbf{R p} 15.000 .000 .000\end{array}$ & $>\mathbf{R p 1 5 . 0 0 0 . 0 0 0 . 0 0 0}$ \\
\hline $1-19$ orang & $\begin{array}{l}\text { Industri Kecil (tidak } \\
\text { termasuk tanah dan } \\
\text { bangunan usaha) }\end{array}$ & Industri Menengah & Industri Menengah \\
\hline$\geq 20$ orang & Industri Menengah & Industri Menengah & Industri Besar \\
\hline
\end{tabular}

Sumber: Lampiran Permenperin Nomor 64 Tahun 2016

Lebih lanjut Kuncoro (2007:205) menjelaskan masalah dasar yang dihadapi pengusaha kecil, yaitu:(1) kelemahan dalam memperoleh peluang pasar dan memperbesar pangsa pasar; (2)kelemahan dalam struktur permodalan dan keterbatasan untuk memperoleh jalur terhadap sumber-sumber permodalan; (3) kelemahan di bidang organisasi dan manajemen sumberdaya manusia; (4) keterbatasan jaringan usaha kerjasama antar pengusaha kecil (sistem informasi pemasaran); (5) iklim usaha yang kurang kondusif, karena persaingan yang saling mematikan; (6) pembinaan yang telah dilakukan masih kurang terpadu dan kurangnya kepercayaan serta kepedulian masyarakat terhadap usaha kecil. 


\section{HASIL DAN PEMBAHASAN}

\section{Perencanaan Program}

Secara umum, proses penyusunan perencanaan program pembinaan dan pengembangan IKM di Kabupaten Ponorogo telah menggunakan kolaborasi top-down dan bottom-up, akan tetapi dengan porsi perencanaan top-down lebih besar dibandingkan dengan bottom-up. Perencanaan top-down ini terlihat pada saat penentuan dasar prioritas dan kerangka pembangunan serta menjembatani rencana dari institusi yang lebih tinggi dalam hal ini, yaitu Kementerian Perindustrian sebagai perencana dalam pembangunan IKM skala nasional. Sedangkan perencanaan bottom-up dilakukan Dinas Indakop dan UKM dengan menampung kebutuhan masyarakat dalam meningkatkan usaha IKM melalui usulan yang disampaikan dalam Musrenbang maupun secara langsung. Seperti yang disampaikan oleh Kuncoro (2004:58) bahwa sistem perencanaan pembangunan dengan mengunakan top-down dan bottom-up akan menjamin adanya keseimbangan antara prioritas nasional dengan aspirasi lokal dalam perencanaan pembangunan daerah.

Tujuan pelaksanaan program ini telah sesuai dengan tujuan Dinas Indakop dan UKM Kabupaten Ponorogo, dimana salah satunya bertujuan untuk menumbuhkan dan mengembangkan IKM di Kabupaten Ponorogo yang tangguh, professional dan berdaya saing. Hal tersebut sesuai dengan tujuan pembangunan daerah dalam meningkatkan daya saing dan struktur ekonomi daerah, salah satunya melalui sektor industri khususnya IKM, sebagaimana tertuang dalam RPJMD. Akan tetapi dari sisi administratif, dari hasil evaluasi terhadap dokumen perencanaan, masih terdapat inkonsistensi terhadap dokumen Renja dan Renstra Dinas Indakop dan UKM Kabupaten Ponorogo. Pada dokumen Renstra terdapat beberapa aspek yang tidak sesuai dengan Permendagri Nomor 54 Tahun 2010 diantaranya: (1) belum mencantumkan Permendagri Nomor 54 Tahun 2010, sehingga terdapat ketidaksesuaian sistematikan penulisan; (2) tidak disahkannya penetapan dokumen Renstra oleh Bupati menjadi produk hukum. Demikian pula pada dokumen Renja, masih terdapat beberapa item yang belum termuat sesuai dengan peraturan, diantaranya tidak adanya: (1) indikator kinerja dan kelompok sasaran yang menggambarkan pencapaian Renstra SKPD; (2) dana indikatif beserta sumbernya serta prakiraan maju berdasarkan pagu indikatif; dan (3) sumber dana yang dibutuhkan untuk menjalankan program dan kegiatan.

\section{Pelaksanaan Program}

Proses pelaksanaan program pembinaan dan pengembangan IKM berdasarkan Dokumen Pelaksanaan Anggaran (DPA) Dinas Indakop dan UKM. Secara umum, program ini dilaksanakan dalam jenis pelatihan teknis dan pelatihan non-teknis (manajerial), dimana jumlah pelatihan teknis yang diberikan lebih banyak, hal ini sudah tepat untuk mencapai tujuan program dalam meningkatan keterampilan SDM pengrajin serta berupaya meningkatkan pertumbuhan wirausaha baru. Sedangkan pelatihan non-teknis bersifat manajerial diperuntukkan bagi pengrajin IKM yang telah memiliki usaha.

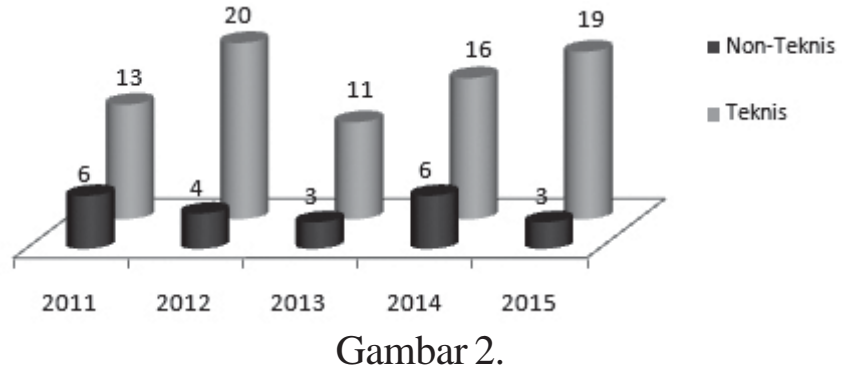

Grafik Jumlah dan Jenis Pelatihan Tahun 2011-2015

Sumber: Dokumen Pelaksanaan Kegiatan Bidang Industri (2011-2015) 
Menurut Wahjono (2015:76) menjelaskan langkah-langkah umum dalam proses pelatihan dan pengembangan, yaitu: (1) penilaian dan analisis kebutuhan, (2) desain program pelatihan, (3) pengembangan program pelatihan; (4) pelaksanaan dan penyampaian pelatihan; dan (5) evaluasi pelatihan.

Berdasarkan teori tersebut, Bidang Industri telah menerapkan beberapa diantaranya, namun belum keseluruhan diterapkan, khususnya dalam tahap evaluasi pelatihan, baru hanya pada saat pelatihan Fasilitasi Sertifikasi Produk Industri Makanan Minuman, dimana terdapat evaluasi berupa peningkatan pengetahuan sebelum dan sesudah pelatihan berupa pre-test dan post-test. Seharusnya penerapan evaluasi ini dilakukanpadaseluruh pelatihan yang diselenggarakan agar dapat terukur berapa besarpenyerapanmateri oleh peserta, serta bagaimana pencapaian target output pelatihan terhadap indikator kinerja.

Dalam pelaksanaannya, masih terdapat hambatan-hambatan diantaranya sebagai berikut:

1. Alokasi anggaran yang terbatas.

"Alokasi merupakan kendala sekaligus pemicu. Kendala karena ketersediaan anggaran belum sesuai dengan kehendak IKM. Jadi sementara ini kita masih menerapkan sistem prioritas program, dari sekian banyak permasalahan IKM mana yang lebih dulu, dari skala sangat prioritas hingga yang tidak prioritas. Misal daerah X klaster usaha tertentu ingin meningkatkan usaha ke packing, ijin, pengembangan bahan baku. Nah, diantara itu, kita memilah mana yang segera dilakukan mana yang tidak kemudian disesuaikan dengan anggaran yang tersedia” (Vifson Suisno, Kepala Dinas Indakop dan UKM Kabupaten Ponorogo, Wawancara 20 Juni 2016).

Dengan alokasi anggaran yang terbatas, merupakan tantangan bagi Dinas Indakop dan UKM dalam membina IKM yang jumlahnya mencapai 19.706 unit sehingga diperlukan pengelolaan sumber daya anggaran secara efektif dan efisen agar dengan alokasi yang terbatas mampu mengakomodir kebutuhan IKM dengan skala prioritas. Oleh karena itu perlu adanya pembenahan mengenai penyusunan perencanaan jenis-jenis pelatihan yang akan direncanakan pada tahun mendatang.

2. Sumber Daya Manusia (SDM) Aparatur Bidang Industri yang terbatas.

Keterbatasan SDM Industri yang hanya 13 orang dalam melaksanakan 15-25 jenis pelatihan selama 1 tahun anggaran (7 bulan efektif) sehingga diperlukan adanya penjadwalan panitia pelaksana yang baik dan bergantian.

3. Sistem perekrutan calon peserta.

Permasalahan ketidak sesuaian antara latar belakang calon peserta dengan jenis pelatihan yang akan diikuti, seperti yang disampaikan oleh Ibu Yeni, pengrajin IKM kerajinan resleting yang diikutsertakan sebagai peserta Pelatihan Desain dan Pewarnaan Alam Batik Tulis, berikut: "Kalau jadi peserta pelatihan dari Indakop waktu itu pelatihan batik, memang tidak sesuai, tapi jadi tahu bagaimana membatik.” (Wawancara 23 Juni 2016).

Sehingga perlu adanya pembenahan dalam sistem perekrutan calon peserta. Perlu monitoring Kepala Bidang kepada Kepala Seksi selaku pelaksana terhadap penyelenggaraan pelatihan pengembangan keterampilan, sehingga calon peserta memiliki usaha sesuai dengan jenis pelatihan yang akan diikutinya.

4. Ketidakhadiran peserta

Ketidakhadiran peserta dapat diatasi dengan komitmen tinggi setiap individu yang perlu disampaikan oleh panitia pelaksana kepada calon peserta. 
5. Terdapat jenis pelatihan yang belum sesuai dengan kebutuhan peserta

Permasalahan ini dapat diatasi dengan peninjauan kembali dalam proses penyusunan rencana kerja, dimana lebih mengutamakan perencanaan bottom-up dimana aspirasi kebutuhan akan pelatihan dapat terselenggara.

Kelima hambatan tersebut di atas sejalan dengan apa yang disampaikan oleh Ridwan (2014:12) yang menjabarkan faktor-faktor yang menghambat pembinaan Industri Kecil Dan Menengah pada Dinas Perindagkop Kota Bontang, antara lain: (1) kurangnya aparat pembina IKM, (2) kompetensi / basic pendidikan aparat yang tidak sesuai, (3) alokasi anggaran; (4) karakteristik dan pola pikir IKM; dan (4) kurangnya perencanaan secara matang dalam pelaksanaannya.

\section{Output Program}

Evaluasi program pembinaan dan pengembangan IKM merupakan evaluasi sumatif dimana dilakukan pada saat implementasi sudah selesai dilakukan dan berfokus pada penilaian tentang sejauh mana hasil dan dampak pelaksanaan kebijakan memberikan kontribusi pada pencapaian tujuan kebijakan. Berdasarkan hasil wawancara kepada 6 (enam) orang pengrajin IKM yang telah mengikuti program pelatihan dari Bidang Industri Dinas Indakop dan UKM ditabulasikan sebagai berikut:

Tabel 3.

Wujud Hasil Peningkatan IKM Pasca Mengikuti Pelatihan

\begin{tabular}{|c|l|c|c|c|c|c|c|c|}
\hline No. & \multicolumn{1}{|c|}{$\begin{array}{c}\text { Wujud } \\
\text { Peningkatan }\end{array}$} & \multicolumn{2}{c|}{$\begin{array}{c}\text { IKM - } \\
\text { IHPK }\end{array}$} & \multicolumn{2}{c|}{ IKM - IKBB } & \multicolumn{2}{c|}{$\begin{array}{c}\text { IKM - } \\
\text { ILMEA }\end{array}$} & \multicolumn{2}{c|}{$\begin{array}{c}\text { Total } \\
\text { Responden }\end{array}$} \\
\cline { 3 - 8 } & $\begin{array}{c}\text { Ibu } \\
\text { Lusia }\end{array}$ & $\begin{array}{c}\text { Ibu } \\
\text { Rida }\end{array}$ & $\begin{array}{c}\text { Bp. } \\
\text { Marjuki }\end{array}$ & $\begin{array}{c}\text { Bp. } \\
\text { Toheran }\end{array}$ & $\begin{array}{c}\text { Ibu } \\
\text { Yani }\end{array}$ & $\begin{array}{c}\text { Ibu } \\
\text { Yeni }\end{array}$ & \\
\hline 1. & $\begin{array}{l}\text { Pertumbuhan } \\
\text { Wirausaha baru }\end{array}$ & & $\sqrt{ }$ & & & & & 1 \\
\hline 2. & $\begin{array}{l}\text { Peningkatan } \\
\text { pengetahuan }\end{array}$ & $\sqrt{ }$ & $\sqrt{ }$ & $\sqrt{ }$ & $\sqrt{ }$ & $\sqrt{ }$ & $\sqrt{ }$ & 6 \\
\hline 3. & $\begin{array}{l}\text { Peningkatan } \\
\text { keterampilan }\end{array}$ & $\sqrt{ }$ & $\sqrt{ }$ & & $\sqrt{ }$ & $\sqrt{ }$ & & 4 \\
\hline 4. & $\begin{array}{l}\text { Peningkatan } \\
\text { omzet usaha }\end{array}$ & $\sqrt{ }$ & $\sqrt{ }$ & & $\sqrt{ }$ & $\sqrt{ }$ & & 4 \\
\hline 5. & $\begin{array}{l}\text { Perluasan area } \\
\text { pemasaran }\end{array}$ & $\sqrt{ }$ & & & & $\sqrt{ }$ & \\
\hline
\end{tabular}

Sumber : Hasil Analisa Data Primer (2016)

Berdasarkan tabel atas dapat disimpulkan bahwa hasil program pembinaan dan pengembangan IKM berupa pelaksanaan pelatihan berwujud terhadap peningkatan pengetahuan pengrajin IKM. Tahap tingkatan pengetahuan ini masih berada dalam tahap permulaan, dimana setelah mengikuti pelatihan menjadikan pengrajin IKM mendapatkan informasi dan pengetahuan baru, sehingga belum menunjukkan terhadap peningkatan keterampilan teknis maupun manajerial.

Meninjau kembali terhadap tujuan pelaksanaan program pembinaan dan pengembangan IKM yaitu: (1) kontribusi sektor industri terhadap PDRB; dan (2) pertumbuhan industri baru. Terkait dengan pertumbuhan industri baru terlihat pada Tabel 1. di atas terlihat pertumbuhan IKM pada 
tahun 2015 hanya 2 unit. Berdasarkan hasil wawancara, rendahnya pertumbuhan industri baru disebabkan karena beberapa hal diantaranya:

1. Minimnya kegiatan monitoring dan evaluasi internal yang dilakukan oleh Bidang Industri, khususnya pasca pelatihan sehingga tidak dapat diukur secara cermat mengenai berapa jumlah IKM yang tumbuh;

2. Belum adanya review kembali terhadap perencanaan target yang terlalu tinggi pada tahun berjalan karena berbagai macam faktor dapat menyebabkan ketidakstabilan ekonomi yang menyebabkan penurunan jumlah industri pada tahun 2013;

3. Pihak perencana seharusnya lebih spesifik dalam menentukan indikator kinerja, dimana tidak lagi berupa kontribusi sektor industri pengolahan terhadap PDRB, tetapi dari hanya melalui sektor industri kecil saja. Hal ini dimungkinan terdapat kontribusi yang lebih besar yang diperoleh dari sektor industri besar dan menengah, walaupun dengan jumlah industri yang sedikit. Selain itu indikator pertumbuhan industri juga harus di spesifikan menjadi pertumbuhan IKM saja yang disesuaikan dengan tugas pokok dan fungsi dari Dinas Indakop dan UKM adalah membina IKM.

\section{Evaluasi Dampak Peningkatan Keterampilan Pengrajin IKM}

Berdasarkan hasil wawancara dan pengamatan langsung di lapangan menunjukkan bahwa tingkat keterampilan yang diterima oleh setiap pengrajin IKM yang menerima program pembinaan dan pengembangan IKM sangat beragam. Dalam penelitian ini dilakukan perbandingan terhadap keterampilan dari Pengrajin IKM yang didapatkan melalui pelatihan-pelatihan pada program pembinaan dan pengembangan IKM dibandingkan dengan pengrajin IKM lain yang belum pernah menerima pelatihan dari Dinas Indakop dan UKM. Adapun informan dalam penelitian ini adalah perwakilan dari keseluruhan pengrajin yang ada di Kabupaten Ponorogo terdiri dari IKM IHPK, IKBB dan ILMEA. 
Tabel 4.

Perbandingan Dampak Program Pembinaan dan Pengembangan IKM Terhadap Peningkatan Keterampilan IKM Industri Kerajinan Hasil Hutan dan Pertanian (IHPK)

\begin{tabular}{|c|c|c|c|c|}
\hline Uraian & \multicolumn{2}{|c|}{ Telah Mengikuti Pelatihan } & \multicolumn{2}{|c|}{$\begin{array}{c}\text { Belum Pernah Mengikuti } \\
\text { Pelatihan }\end{array}$} \\
\hline Nama & Ibu Lusia & Ibu Rida & Ibu Yatmi & Ibu Wahyu \\
\hline Usaha & $\begin{array}{l}\text { IKM Janggelan } \\
\text { "Segariin" }\end{array}$ & $\begin{array}{l}\text { IKM Makanan "Ria } \\
\text { Boga" }\end{array}$ & $\begin{array}{l}\text { IKM Otak-otak } \\
\text { Bandeng }\end{array}$ & $\begin{array}{l}\text { IKM Kacang } \\
\text { Mente } \\
\text { "UD. Wahyu" }\end{array}$ \\
\hline $\begin{array}{l}\text { Jenis } \\
\text { Pelatihan }\end{array}$ & $\begin{array}{l}\text { 1. Pelatihan } \\
\text { Pengolahan } \\
\text { Janggelan } \\
\text { 2. Fas. Sertifikasi } \\
\text { Produk Ind. } \\
\text { Mamin (PIRT) } \\
\text { 3. Pel.Desain } \\
\text { Kemasan }\end{array}$ & $\begin{array}{l}\text { 1. Pembinaan } \\
\text { Industri di Lokasi } \\
\text { P2WKSS } \\
\text { 2. Fas. Sertifikasi } \\
\text { Produk Ind. } \\
\text { Mamin (PIRT) } \\
\text { 3. Pel. Desain } \\
\text { Kemasan }\end{array}$ & - & - \\
\hline $\begin{array}{l}\text { Kondisi } \\
\text { Sebelum } \\
\text { Mengikuti } \\
\text { Pelatihan }\end{array}$ & $\begin{array}{l}\text { Usaha olahan } \\
\text { minuman sari } \\
\text { janggelan masih } \\
\text { menggunakan } \\
\text { mesin sederhana } \\
\text { dan pemasaran } \\
\text { sekitar Ponorogo. }\end{array}$ & $\begin{array}{l}\text { Hanya ibu rumah } \\
\text { tangga biasa dan } \\
\text { menggantungkan } \\
\text { kehidupan dari } \\
\text { pekerjaan suami. }\end{array}$ & $\begin{array}{l}\text { Cara mengolah } \\
\text { produk dan } \\
\text { bentuk } \\
\text { kemasan masih } \\
\text { sederhana. }\end{array}$ & $\begin{array}{l}\text { Belum } \\
\text { mampu } \\
\text { mengupas biji } \\
\text { mente, } \\
\text { sehingga } \\
\text { bahan baku } \\
\text { mentah } \\
\text { dikirim ke } \\
\text { luar daerah } \\
\text { (Wonogiri). }\end{array}$ \\
\hline $\begin{array}{l}\text { Peningkatan } \\
\text { Keterampilan }\end{array}$ & $\begin{array}{l}\text { Peningkatan } \\
\text { pengetahuan } \\
\text { pengolahan } \\
\text { janggelan, dan } \\
\text { peningkatkan } \\
\text { keterampilan } \\
\text { dalam mendesain } \\
\text { kemasan yang } \\
\text { baik. }\end{array}$ & $\begin{array}{l}\text { Peningkatan } \\
\text { pengetahuan } \\
\text { mengenai memulai } \\
\text { usaha olahan pangan } \\
\text { berupa kue bolu dan } \\
\text { bakpia telo ungu, } \\
\text { mendapatkan } \\
\text { kemudahan dalam } \\
\text { mendapatkan izin } \\
\text { PIRT dalam } \\
\text { pemasaran produk. }\end{array}$ & $\begin{array}{l}\text { Tidak ada } \\
\text { inovasi dalam } \\
\text { pembuatan } \\
\text { otak-otak } \\
\text { bandeng, baik } \\
\text { dalam rasa } \\
\text { maupun } \\
\text { kemasan. } \\
\text { Bentuk dan } \\
\text { desain kemasan } \\
\text { masih } \\
\text { sederhana. }\end{array}$ & $\begin{array}{l}\text { Masih } \\
\text { mengalami } \\
\text { kesulitan } \\
\text { dalam } \\
\text { mengolah } \\
\text { bahan baku, } \\
\text { terutama } \\
\text { dalam } \\
\text { penyimpanan } \\
\text { dan } \\
\text { pengupasan } \\
\text { kacang mente. }\end{array}$ \\
\hline
\end{tabular}

Sumber : Hasil Analisa Data Primer (2016) 
Tabel 5.

Perbandingan Dampak Program Pembinaan dan Pengembangan IKM Terhadap Peningkatan Keterampilan IKM Industri Kimia dan Bahan Bangunan (IKBB)

\begin{tabular}{|c|c|c|c|c|}
\hline Uraian & \multicolumn{2}{|c|}{ Telah Mengikuti Pelatihan } & \multicolumn{2}{|c|}{$\begin{array}{c}\text { Belum Pernah Mengikuti } \\
\text { Pelatihan }\end{array}$} \\
\hline Nama & Bapak Marjuki & Bapak Toheran & Bapak Kamo & Ibu Dammi \\
\hline Usaha & IKM Genteng & IKM Genteng & IKM Genteng & IKM Bata \\
\hline $\begin{array}{l}\text { Jenis } \\
\text { Pelatihan }\end{array}$ & $\begin{array}{l}\text { Pelatihan AMT } \\
\text { (Achievement } \\
\text { Motivation } \\
\text { Training) }\end{array}$ & $\begin{array}{l}\text { Pelatihan AMT } \\
\text { (Achievement } \\
\text { Motivation } \\
\text { Training) danGKM } \\
\text { (Gugus Kendali } \\
\text { Mutu) }\end{array}$ & - & - \\
\hline $\begin{array}{l}\text { Kondisi } \\
\text { Sebelum Ikut } \\
\text { Pelatihan }\end{array}$ & $\begin{array}{l}\text { Terkadangmasih } \\
\text { merasa malas } \\
\text { dalam bekerja, } \\
\text { tidak ada } \\
\text { motivasi. }\end{array}$ & $\begin{array}{l}\text { Tidak ada motivasi } \\
\text { bekerja, dan banyak } \\
\text { permasalahan baik } \\
\text { daribahan baku, } \\
\text { proses produksi } \\
\text { yangbelum } \\
\text { terpecahkan }\end{array}$ & $\begin{array}{l}\text { Pembuatan } \\
\text { genteng } \\
\text { dilakukan } \\
\text { berdasarkan } \\
\text { pesanan, harya } \\
\text { memproduksi } 4 \\
\text { macamgenteng }\end{array}$ & $\begin{array}{l}\text { Pembuatan } \\
\text { batubata } \\
\text { masih } \\
\text { dilakukan } \\
\text { secara } \\
\text { manual. }\end{array}$ \\
\hline $\begin{array}{l}\text { Peningkatan } \\
\text { Keterampilan }\end{array}$ & $\begin{array}{l}\text { Belum ada, } \\
\text { karenajenis } \\
\text { pelatihanyng } \\
\text { diberikan harrya } \\
\text { berupa motivasi. } \\
\text { Bukan berupa } \\
\text { pelatihantekrik } \\
\text { pengembangan } \\
\text { pembuatan } \\
\text { genteng. }\end{array}$ & $\begin{array}{l}\text { MenerapkanGKM } \\
\text { dalam bekerja } \\
\text { sehingga bahan baku } \\
\text { dan penurjang } \\
\text { dalam produksi } \\
\text { dapat dimanfaatkan } \\
\text { serta membantu } \\
\text { memecahkan } \\
\text { permasalahan kerja. }\end{array}$ & $\begin{array}{l}\text { Tidak a daryya } \\
\text { inovasi dalam } \\
\text { pembuatan } \\
\text { genteng, } \\
\text { sehingga masih } \\
\text { kalah bersaing } \\
\text { dengan hasil } \\
\text { pabrik. }\end{array}$ & $\begin{array}{l}\text { Tidak a darya } \\
\text { inovasi dalam } \\
\text { pembuatan } \\
\text { batu bata, } \\
\text { sehingga } \\
\text { masihkalah } \\
\text { bersaing } \\
\text { dengan hasil } \\
\text { pabrik. }\end{array}$ \\
\hline
\end{tabular}

Sumber : Hasil Analisa Data Primer (2016) 
Tabel 6.

Perbandingan Dampak Program Pembinaan dan Pengembangan IKM Terhadap Peningkatan Keterampilan IKM Industri Logam, Mesin, Aneka dan Kerajinan (ILMEA)

\begin{tabular}{|l|l|l|l|l|}
\hline \multicolumn{1}{|c|}{ Uraian } & \multicolumn{2}{|c|}{ Telah Mengikuti Pelatihan } & \multicolumn{2}{c|}{$\begin{array}{c}\text { Belum Pernah Mengikuti } \\
\text { Pelatihan }\end{array}$} \\
\hline Nama & Ibu Yani & Ibu Yeni & Mbah Kusnan & Bapak Kethut \\
\hline Usaha & $\begin{array}{l}\text { IKM "Yani } \\
\text { Bordier" }\end{array}$ & $\begin{array}{l}\text { IKM Resleting } \\
\text { "Zaharaya" }\end{array}$ & $\begin{array}{l}\text { IKM Kerajinan } \\
\text { Gamelan }\end{array}$ & $\begin{array}{l}\text { IKM Kerajinan } \\
\text { Reyog }\end{array}$ \\
\hline $\begin{array}{l}\text { Jenis } \\
\text { Pelatihan }\end{array}$ & $\begin{array}{l}\text { Pel.Keterampilan } \\
\text { Konveksi; } \\
\text { Pel. Desain dan } \\
\text { Pola Konveksi. }\end{array}$ & $\begin{array}{l}\text { Pel. Desain dan } \\
\text { Pewarnaan Alam } \\
\text { Batik Tulis. }\end{array}$ & - & - \\
\hline $\begin{array}{l}\text { Kondisi } \\
\text { Sebelum Ikutihan }\end{array}$ & $\begin{array}{l}\text { Usaha konveksi } \\
\text { dan bordier } \\
\text { sudah banyak } \\
\text { menerima } \\
\text { pesanan. }\end{array}$ & $\begin{array}{l}\text { Pioner dalam } \\
\text { merintis usaha tas / } \\
\text { dompet dari } \\
\text { resleting di } \\
\text { Ponorogo. }\end{array}$ & $\begin{array}{l}\text { Keterampilan } \\
\text { pembuatan } \\
\text { gamelan sudah } \\
\text { sejak 20 tahun } \\
\text { yang lalu. }\end{array}$ & $\begin{array}{l}\text { Keterampilan } \\
\text { pembuatan } \\
\text { reyog warisan } \\
\text { turun-temurun. }\end{array}$ \\
\hline $\begin{array}{l}\text { Peningkatan } \\
\text { Keterampilan }\end{array}$ & $\begin{array}{l}\text { Pengetahuan } \\
\text { mengenai } \\
\text { keterampilan } \\
\text { bordier semakin } \\
\text { bertambah. }\end{array}$ & $\begin{array}{l}\text { Peningkatan } \\
\text { pengetahuan dalam } \\
\text { mendesain dan } \\
\text { teknik membatik. } \\
\text { Tetapi tidak } \\
\text { berkorelasi } \\
\text { terhadap usaha } \\
\text { yang dimiliki. }\end{array}$ & $\begin{array}{l}\text { Inovasi } \\
\text { pembuatan } \\
\text { mengikuti } \\
\text { pesanan. }\end{array}$ & $\begin{array}{l}\text { Tidak } \\
\text { inovasi. }\end{array}$ \\
& & ada & \\
& & & \\
\hline
\end{tabular}

Sumber : Hasil Analisa Data Primer (2016)

Berdasarkan tabel di atas menunjukkan bahwa terdapat perbedaan peningkatan keterampilan dari pengrajin IKM yang telah mengikuti pelatihan dibandingkan dengan pengrajin yang belum mengikuti pelatihan. Pada IKM IHPK terlihat jelas kemampuan pengrajin IKM dalam mendesain kemasan (packaging), dimana kemasan telah dicetak sedangkan pada kemasan IKM yang belum mendapatkan pelatihan masih sederhana dan kurang menarik. Akan tetapi, belum secara keseluruhan dapat mengakomodir kebutuhan IKM, misalnya memfasilitasi keterampilan pengupasan biji mente, maka biaya produksi yang selama ini masih mengandalkan daerah tetangga dapat tertekan sehingga dapat meningkatkan laba dan kesejahteraan IKM.

Pada kelompok IKM IKBB, peningkatan keterampilan lebih mengena kepada IKM apabila diberikan pelatihan teknis yang langsung berhubungan dengan bagaimana untuk meningkatkan mutu produk yang dihasilkan. Sementara itu, IKM yang belum pernah mendapatkan pelatihan masih menggunakan teknik yang sama sejak mereka melakukan awal produksi, tanpa memberikan inovasi dalam teknik produksi mereka.Sedangkan pada kelompok IKM ILMEA menunjukkan dampak peningkatan keterampilan sangat terlihat pada IKM kerajinan bordir berupa peningkatan pengetahuan dalam membordier, hal ini disebabkan kebutuhan akan keterampilan dalam usaha konveksi telah diakomodir oleh Dinas Indakop. Selama ini bidang usaha kerajinan konveksi, batik, dan bambu telah diakomodir, tetapi belum mengakomodir kebutuhan akan pelatihan peningkatan keterampilan dari usaha kerajinan reog, kerajinan gamelan dan kerajinan lainnya. 
Secara keseluruhan perencanaan pemilihan jenis pelatihan telah disesuaikan dalam peruntukannya, misalnya penyelenggaraan pelatihan pembuatan roti dan kue dengan peserta calon wirausaha baru diharapkan berdampak untuk meningkatakan keterampilan calon WUB sehingga dapat membuka usaha sendiri. Selain itu pelaksanaan pelatihan juga terkait dengan pemanfaatan sumber daya alam sekitar, misalnya pelatihan pembuatan anyaman mendong, dimana tanaman mendong sangat melimpah di Desa Puhijo Kecamatan Sampung, sehingga penyelenggaraan pelatihan ini diharapkan berdampak untuk meningkatakan keterampilan bagi pengrajin anyaman mendong agar dapat membut produk-produk kerajinan mendong dengan nilai ekonomis yang lebih tinggi seperti tas, dompet dan sebagainya jika dibandingkan dengan anyaman berupa tikar mendong saja.

\section{Evaluasi Dampak Peningkatan Kesejahteraan Pengrajin IKM}

Sebagaimana yang telah dijelaskan bahwa tujuan program ini mendukung tujuan pembangunan ekonomi di Kabupaten Ponorogo, maka diperlukannya suatu evaluasi mengenai peningkatan kesejahteraan pengrajin IKM yang merupakan salah satu outcome (dampak). Pada penelitian ini menggunakan indikator kesejahteraan yang ditetapkan Badan Pusat Statistik (2015:61) sebagai berikut:

1. Kondisi sosial demografi, dengan indikator: jumlah penduduk, laju pertumbuhan penduduk eksponensial, rasio jenis kelamin, kepadatan penduduk, komposisi penduduk, angka beban ketergantungan dan fertilitas;

2. Kesehatan, dengan indikator: derajat dan status kesehatan penduduk, tingkat imunitas dan gizi balita, dan pemanfaatan fasilitas tenaga kesehatan;

3. Pendidikan, dengan indikator: angka melek huruf, tingkat pendidikan, angka partisipasi kasar dan angka partisipasi murni;

4. Ketenagakerjaan, dengan indikator: tingkat partisipasi angkatan kerja, tingkat pengangguran terbuka, tingkat pendidikan, lapangan usaha, upah/gaji/pendapatan bersih dan prosentasi pekerja anak;

5. Taraf dan pola konsumsi, dengan indikator: pengeluaran konsumsi rumah tangga, konsumsi energi dan protein;

6. Perumahan dan lingkungan, dengan indikator: kualitas rumah tinggal, fasilitas rumah tinggal, dan status kepemilikan rumah tinggal

Berdasarkan indikator-indikator tersebut di atas, maka pada penelitian ini dipilih indikator yang berhubungan dengan tingkat kesejateraan masyarakat khususnya pengrajin IKM yang menerima program pembinaan dan pengembangan IKM dari Dinas Indakop dan UKM, antara lain: (1) tingkat pendidikan; (2) konsumsi rumah tangga; dan (3) kualitas rumah tinggal. Serta adanya penambahan indikator terkait peningkatan omzet penjualan. Berikut merupakan perbandingan dampak peningkatan kesejahteraan yang dialami oleh 6 (enam) orang responden kelompok pengrajin IKM yang telah mendapatkan pelatihan dengan 6 (enam) orang responden pengrajin IKM yang belum mendapatkan pelatihan dapat terlihat pada Tabel 7 sebagai berikut: 
Tabel 7.

Perbandingan Dampak Program Pembinaan dan Pengembangan IKM Terhadap Peningkatan Kesejahteraan IKM

\begin{tabular}{|c|c|c|c|c|c|c|}
\hline Uraian & \multicolumn{2}{|c|}{ IKM IHPK } & \multicolumn{2}{|c|}{ IKM IKBB } & \multicolumn{2}{|c|}{ IKM ILMEA } \\
\hline Nama & Ibu Lusia & \begin{tabular}{|l|l} 
Ibu Rida \\
\end{tabular} & Bp.Marjuki & Bp.Toheran & Ibu Yani & Ibu Yeni \\
\hline Jenis Usaha & $\begin{array}{l}\text { IKM } \\
\text { Minuman } \\
\text { "Segariin" }\end{array}$ & $\begin{array}{l}\text { IKM } \\
\text { Makanan } \\
\text { "Ria Boga" }\end{array}$ & $\begin{array}{l}\text { IKM } \\
\text { Genteng }\end{array}$ & IKM Genteng & $\begin{array}{l}\text { IKM } \\
\text { Kerajinan } \\
\text { "Yani } \\
\text { Bordier" }\end{array}$ & $\begin{array}{l}\text { IKM } \\
\text { Kerajinan } \\
\text { "Zaharaya" }\end{array}$ \\
\hline $\begin{array}{l}\text { Sumber } \\
\text { Pendapatan } \\
\text { Keluarga }\end{array}$ & $\begin{array}{l}\text { Usaha } \\
\text { Janggelan, } \\
\text { Suami } \\
\text { bekerja }\end{array}$ & $\begin{array}{l}\text { Usaha Roti, } \\
\text { Suami tidak } \\
\text { bekerja }\end{array}$ & $\begin{array}{l}\text { Lurah dan } \\
\text { Genteng, } \\
\text { Istri tidak } \\
\text { bekerja }\end{array}$ & $\begin{array}{l}\text { Usaha } \\
\text { Genteng, Istri } \\
\text { tidak bekerja }\end{array}$ & $\begin{array}{l}\text { Usaha } \\
\text { Bordier, } \\
\text { Suami } \\
\text { bekerja }\end{array}$ & $\begin{array}{l}\text { Usaha } \\
\text { Resleting, } \\
\text { Suami tidak } \\
\text { bekerja }\end{array}$ \\
\hline $\begin{array}{l}\text { Pendidikan: } \\
\text {-KK } \\
\text {-Anak }\end{array}$ & $\begin{array}{l}\text {-Sarjana } \\
\text {-Sarjana }\end{array}$ & $\begin{array}{l}\text {-Sarjana } \\
\text {-Sarjana }\end{array}$ & $\begin{array}{l}\text {-Sarjana } \\
\text {-SMA }\end{array}$ & $\begin{array}{l}\text {-SMA } \\
\text {-Sarjana }\end{array}$ & $\begin{array}{l}\text {-SMA } \\
\text {-Sarjana }\end{array}$ & $\begin{array}{l}\text {-SMA } \\
\text {-SD (Balita) }\end{array}$ \\
\hline $\begin{array}{l}\text { Konsumsi } \\
\text { Rumah } \\
\text { Tangga: } \\
\text {-Makanan } \\
\text {-Bukan } \\
\text { Makanan }\end{array}$ & $\begin{array}{l}-40 \% \\
-60 \%\end{array}$ & $\begin{array}{l}-55 \% \\
-45 \%\end{array}$ & $\begin{array}{l}-40 \% \\
-60 \%\end{array}$ & $\begin{array}{l}-45 \% \\
-55 \%\end{array}$ & $\begin{array}{l}-40 \% \\
-60 \%\end{array}$ & $\begin{array}{l}-45 \% \\
-55 \%\end{array}$ \\
\hline $\begin{array}{l}\text { Kualitas } \\
\text { Rumah } \\
\text { Tangga }\end{array}$ & $\begin{array}{l}\text { Layak, } \\
\text { Lantai } \\
\text { keramik, } \\
\text { Atap } \\
\text { genteng, dan } \\
\text { Dinding } \\
\text { tembok }\end{array}$ & $\begin{array}{l}\text { Layak, } \\
\text { Lantai tegel, } \\
\text { Atap } \\
\text { genteng, dan } \\
\text { Dinding } \\
\text { tembok }\end{array}$ & $\begin{array}{l}\text { Layak, } \\
\text { lantai tegel, } \\
\text { Atap } \\
\text { genteng, } \\
\text { dan } \\
\text { Dinding } \\
\text { tembok }\end{array}$ & $\begin{array}{l}\text { Layak, Lantai } \\
\text { keramik, Atap } \\
\text { genteng, dan } \\
\text { Dinding } \\
\text { tembok }\end{array}$ & $\begin{array}{l}\text { Layak, } \\
\text { Lantai } \\
\text { keramik, } \\
\text { Atap } \\
\text { genteng, dan } \\
\text { Dinding } \\
\text { tembok }\end{array}$ & $\begin{array}{l}\text { Layak, Lantai } \\
\text { tegel, Atap } \\
\text { genteng, dan } \\
\text { Dinding } \\
\text { tembok }\end{array}$ \\
\hline $\begin{array}{l}\text { Peningkatan } \\
\text { Omzet } \\
\text { Penjualan }\end{array}$ & $\begin{array}{l}\text { Keterampilan } \\
\text { bertambah } \\
\text { serta } \\
\text { mendapatkan } \\
\text { bantuan } \\
\text { mesin, omzet } \\
\text { meningkat. } \\
\text { Area } \\
\text { pemasaran } \\
\text { semakin luas. } \\
\text { Usaha } \\
\text { menjadi } \\
\text { sumber } \\
\text { pendapatan } \\
\text { utama dan } \\
\text { dibantu } \\
\text { penghasilan } \\
\text { suami. }\end{array}$ & $\begin{array}{l}\text { Keterampilan } \\
\text { bertambah } \\
\text { dan } \\
\text { membuka } \\
\text { usaha kue } \\
\text { bolu dan } \\
\text { bakpia. } \\
\text { Suami } \\
\text { mantan guru } \\
\text { honorer, } \\
\text { membantu } \\
\text { pemasaran. } \\
\text { Omzet } \\
\text { meningkat. } \\
\text { Usaha } \\
\text { tumpuan } \\
\text { pendapatan } \\
\text { keluarga. }\end{array}$ & $\begin{array}{l}\text { Penghasilan } \\
\text { utama } \\
\text { berasal dari } \\
\text { jabatan } \\
\text { Lurah. } \\
\text { Tidak adan } \\
\text { peningkatan } \\
\text { produksi } \\
\text { dan omzet } \\
\text { tetap. }\end{array}$ & $\begin{array}{l}\text { Omzet } \\
\text { meningkat, } \\
\text { karena } \\
\text { menerapkan } \\
\text { GKM } \\
\text { bersama } \\
\text { kelompok } \\
\text { dalam satu } \\
\text { sentra untuk } \\
\text { memecahkan } \\
\text { permasalahan. } \\
\text { Usaha } \\
\text { menjadi } \\
\text { sumber } \\
\text { pendapatan } \\
\text { utama }\end{array}$ & $\begin{array}{l}\text { Peningkatan } \\
\text { keterampilan } \\
\text { membordier } \\
\text { bertambah, } \\
\text { sehingga } \\
\text { omzet } \\
\text { meningkat. } \\
\text { Usaha } \\
\text { menjadi } \\
\text { sumber } \\
\text { pendapatan } \\
\text { utama dan } \\
\text { dibantu } \\
\text { penghasilan } \\
\text { suami. }\end{array}$ & $\begin{array}{l}\text { Peningkatan } \\
\text { omzet tidak } \\
\text { dapat } \\
\text { diperhitungkan } \\
\text { karena } \\
\text { mengikuti } \\
\text { pelatihan yang } \\
\text { tidak } \\
\text { berkorelasi } \\
\text { dengan usaha } \\
\text { yang dimiliki. } \\
\text { Sehingga } \\
\text { peningkatan } \\
\text { omzet tidak } \\
\text { dapat } \\
\text { dinyatakan } \\
\text { hasil dari } \\
\text { pelatihan. }\end{array}$ \\
\hline
\end{tabular}

Sumber : Hasil Analisa Data Primer, 2016 (diolah)

Sesuai dengan tujuan dalam penyelenggaraan program ini dimana merupakan salah satu upaya program Pemerintah Kabupaten Ponorogo dalam pembangunan perekonomian daerah, sehingga diharapkan program ini juga berdampak terhadap kesejahtereaan pengrajin IKM. Secara global, keberhasilan pembangunan suatu daerah secara ekonomi diukur dengan besarnya GNP dan GDP 
per kapita. Suatu masyarakat dapat dikatakan sejahtera apabila terhindar dari kemiskinan. Menurut pendapat Korten dalam Suryono (2010:99) bahwa tujuan utama dalam pembangunan adalah pertumbuhan manusia yang didefinisikan sebagai perwujudan yang lebih tinggi dari potensi-potensi manusia. Paradigma ini memberi peran kepada individu tidak semata-mata sebagai obyek, melainkan sebagai pelaku yang menetapkan tujuan, mengendalikan sumber daya, dan mengarahkan proses yang mempengaruhi kehidupannya.

Terdapat beberapa indikator untuk menggambarkan mutu pembangunan suatu wilayah, diantaranya: aspek kesehatan, aspek pendidikan, aspek ketenagakerjaan, aspek taraf dan pola konsumsi serta aspek perumahan dan lingkungan. Pembangunan perekonomian di Kabupaten Ponorogo melalui program pembinaan dan pengembangan IKMdiharapkan berdampak terhadap peningkatan kesejahteraan masyarakat khususnya pengrajin IKM sebagai sasaran program tersebut. Akan tetapi berdasarkan hasil penelitian dampak peningkatan kesejahteraan, dapat disimpulkan bahwa program ini belum berhasil seperti yang diharapkan. Keberhasilan peningkatan kesejahteraan hanya terlihat signifikan pada IKM IHPK khususnya yang memiliki produk makanan dan minuman.

Peningkatan kesejahteraan sangat terlihat pada IKM minuman Janggelan, dimana peningkatan keterampilan usaha minuman sari janggelan dan bantuan peralatan mesin meningkatkan omzet penjualan. Terlebih dengan mengusung keunikan minuman khas daerah membawa Ibu Lusia mendapatkan berbagai penghargaan diantaranya Juara III IKM Pangan Award bidang minuman yang diselenggarakanoleh Dinas Perindustrian dan Perdagangan Jawa Timur Tahun 2013 serta Juara I Citi Micropreneur Award yang diselenggarakan oleh Citibank Tahun 2015. Hal tersebut juga memperluas area pemasaran. Pertumbuhan wirausaha baru yang berhasil juga terlihat pada IKM Ria Boga yang mulai merintis usahanya yang mendapatkan bekal dari keterampilan pembuatan kue bolu dan bakpia dari Pelatihan P2WKKS yang diselenggarakan oleh Dinas Indakop dan UKM yang menjadikan Ibu Rida dari seorang Ibu Rumah Tangga biasanya menjadi lebih produktif dan kini usahanya dapat menjadi tulang punggung perekonomian keluarga.

Pada kelompok IKM IKBB dampak kesejahteraan dari Program belum terlihat maksimal dimana ada salah satu IKM yang menjabat juga sebagai Lurah, sehingga tingkat kesejahteraanya dapat juga bersumber dari pendapatan sebagai Lurah, sedangkan omzet usahanya dapat dikatakan tetap tidak ada peningkatan produksi. Sedangkan IKM Genteng yang lain omzetnya meningkat karena aktif menerapkan sistem GKM dan termasuk pelopor dalam usaha Genteng glasur di wilayah Ponorogo. Begitu pula pada kelompok IKM ILMEA dampak kesejahteraan dari Program juga belum terlihat maksimal, dimana IKM Yani Bordir telah mendapatkan pelatihan dasar dan lanjutan mengenai bordier yang meningkatkan keterampilannya sehingga berdampak pada peningkatan omzet penjualan. Sedangkan pada IKM kerajinan resleting Zaharaya yang mengikuti pelatihan desain batik, dimana tidak berkorelasi pada bidang usaha yang ditekuni, sehingga peningkatan omzet tidak dapat dinyatakan merupakan hasil dari pelatihan.

\section{E. PENUTUP}

Perencanaan program yang telah menggunakan kolaborasi top-down dan bottom-up, dengan porsi top-down yang lebih besar, sehingga diperlukan upaya mensinergikan kedua perencanaan tersebut, agar perumusan pelatihan yang akan diselenggarakan sesuai dengan kebutuhan pengrajin IKM.Program pembinaan dan pengembangan IKM yang dibebankan dalam Dokumen Pelaksanaan Anggaran (DPA) pada Bidang Industri Dinas Indakop dan UKM Kabupaten Ponorogo yang dituangkan ke dalam beberapa penyelenggaraan pelatihan-pelatihan kepada IKM baik teknis maupun tidak. Akan tetapi pada kenyataannya masih terlihat minimnya evaluasi internal yang dilakukan pasca 
pelaksanaan pelatihan. Seharusnya penerapan evaluasi ini dilakukan pada seluruh pelatihan yang diselenggarakan agar dapat terukur berapa besar penyerapan materi oleh peserta, serta bagaimana pencapaian target output pelatihan terhadap indikator kinerja.

Evaluasi dampak peningkatan keterampilan pengrajin IKMmenunjukkan bahwa perbandingan dampak peningkatan keterampilan pada kelompok IKM IHPK terlihat dari adanya perbaikan kualitas dan mutu produk yang dihasilkan, serta kemampuan dalam mendesain kemasan menjadi lebih menarik. Pada IKM IKBB peningkatan keterampilan hanya terlihat pada IKM yang telah mendapatkan pelatihan teknis saja dalam penerapan GKM, tetapi pelatihan motivasi tidak begitu berpengaruh dalam produktivitas. Sedangkan peningkatan keterampilan di bidang kerajinan ILMEA hanya terlihat pada IKM yang mengikuti pelatihan sesuai dengan bidang usaha kerajinannya, masih banyak jenis kerajinan lain yang belum dapat terakomodir, seperti reog dan gamelan.

Evaluasi dampak peningkatan kesejahteraan pengrajin IKM terlihat maksimal pada IKM IHPK, dimana setelah mendapatkan peningkatan keterampilan pembuatan produk, kemudahan fasilitas dan bantuan peralatan berdampak pada peningkatan omzet penjualan. Pada IKM IKBB terdapat IKM yang juga menjabat sebagai Lurah, tetapi tidak ada peningkatan produksinya sehingga omzet tetap, sedangkan IKM serupa omzetnya meningkat karena menerapkan GKM dalam produksinya. Pada IKM ILMEA, IKM Yani Bordier telah mendapatkan pelatihan dasar dan lanjutan sehingga berdampak kepada peningkatan omzet penjualan, sedangkan IKM kerajinan resleting mengikuti pelatihan desain batik, yang tidak berkorelasi pada bidang usahanya, sehingga peningkatan omzet tidak dapat dinyatakan merupakan hasil dari pelatihan.

\section{Rekomendasi}

Berdasarkan kajian terhadap evaluasi dampak pelaksanaan program pembinaan dan pengembangan IKM terhadap pengrajin IKM, beberapa rekomendasi yang dapat dipertimbangkan untuk dilakukan oleh Pemerintah Kabupaten Ponorogo. Pertama, dalam proses penyusunan perencanaan program pembinaan dan pengembangan IKM lebih mensinergiskan porsi perencanaan top-down dan bottom-up yang yang selama ini masih terlihat porsi top-down jauh lebih besar ketimbang bottom-up dan menjaga konsistensi dan keselarasan antara dokumen perencanaan Rencana Strategis (Renstra), Rencana Kerja (Renja) dengan Dokumen Pelaksanaan Anggaran (DPA).

Kedua, dalam proses implementasi seyogyanya melakukan monitoring dan evaluasi dari setiap pelatihan yang dilaksanakan oleh Bidang Industri sehingga dapat terukur prosentase penyampaian materi yang diserap oleh peserta pelatihan. Ketiga, dalam mengantisipasi hambatan teknis, disarankan melakukan pengelolaan sumber daya anggaran secara efektif dan efisen agar dengan alokasi yang terbatas mampu mengakomodir kebutuhan IKM dengan skala prioritas, serta membuat Standard Operating Procedure (SOP) dalam penyelenggaraan pelatihan, sehingga sistem perekrutan calon peserta lebih jelas dan disesuaikan dengan jenis usaha dan pelatihan yang akan diikutinya. Hal ini juga dapat meminimalisir faktor ketidak-hadiran karena setiap peserta memiliki komitmen tinggi untuk hadir demi pengembangan keterampilan dalam usaha mereka. 


\section{DAFTAR PUSTAKA}

Abdul Wahab, Solihin. (2011).Evaluasi Kritis: Reorientasi Evaluasi Kebijakan Publik dan Kebijakan Sosial. Malang: Universitas Brawijaya Press.

Badan Pusat Statistik (2015). Indikator Kesejahteraan Rakyat 2015. Jakarta: BPS Indonesia.

Badan Pusat Statistik (2016). Ponorogo Dalam Angka 2016. Ponorogo: BPS Kabupaten Ponorogo.

Conyers, Diana dan Hills, Peter. (1990). Perencanaan Sosial di Dunia Ketiga Suatu Pengantar. Diterjemahkan oleh Susetiawan dan Affan Gafar. Yogyakarta: Universitas Gajah Mada Press.

Dunn, William N.(2003). Analisis Kebijakan Publik. Yogyakarta: Gajah Mada University Press.

Kementerian Perindustrian Republik Indonesia (2016). Peraturan Menteri Perindustrian Republik Indonesia Nomor 64 Tahun 2016 tentang Besaran Jumlah Tenaga Kerja dan Nilai Investasi Untuk Klasifikasi Usaha Industri. Jakarta.

Kementerian Perindustrian Republik Indonesia (2015). Rencana Strategis Kementerian Perindustrian Tahun 2015-2019. Jakarta.

Kuncoro, Mudrajad. (2004).Otonomi dan Pembangunan Daerah: Reformasi, Perencanaan, Strategi, dan Peluang, Jakarta, Erlangga.

Kuncoro. (2007). Ekonomika Industri Indonesia: Menuju Negara Industri Baru 2030? Yogyakarta: Penerbit Erlangga.

Nugroho, Riant D. (2003).Reinventing Pembangunan: Menata Ulang Paradigma Pembangunan Untuk Membangun Indonesia Baru dengan Keunggulan Global. Jakarta: PT. Gramedia.

Patton, Michael Quinn. (2006). Metode Evaluasi Kualitatif. Diterjemahkan oleh Budi Puspo Priyadi. Yogyakarta: Pustaka Pelajar.

Rakicevic, Zoran, Jasmina Omerbegovic-Bijelovic, Danice Lecic-Cvetkovic. (2016). “A model for effective planning of SME support services". In Elsevier Evaluation and Program Planning 54 (2016):30-40.

Ridwan, Moh., dkk.(2014). Pembinaan Industri Kecil dan Menengah Pada Dinas Perindustrian, Perdagangan, Koperasi dan UMKM Kota Bontang. E-journal Administrative Reform, 2014, 2 (3): 1341-1354.

Riyadi dan Bratakusumah, Deddy Supriady. (2004). Perencanaan Pembangunan Daerah: Strategi Menggali Potensi Dalam Mewujudkan Otonomi Daerah. Jakarta: PT Gramedia Pustaka Utama.

Salusu, J. (2015). Pengambilan Keputusan Stratejik Untuk Organisasi Publik dan Organisasi Non Profit. Jakarta: PT. Gramedia Widiasarana Indonesia. 
Suryono, Agus. (2010). Dimensi-dimensi Prima Teori Pembangunan. Malang: Universitas Brawijaya Press.

Wahjono, Sentot Imam. (2015). Manajemen Sumber Daya Manusia. Jakarta: Penerbit: Salemba Empat.

Wirawan. (2011). Evaluasi (Teori, Model, Standar, Aplikasi, dan Profesi). Jakarta: PT. Raja Grafindo Persada. 